\title{
Spiritual Journey of Protagonists in Saul Bellow's Fictions: Search-Escape-Regeneration
}

\author{
Fei Luo \\ School of Foreign Language, Jiangxi Science and Technology Normal University, Nanchang, Jiangxi, China
}

\begin{abstract}
Saul Bellow, the author of Herzog, became first American Jewish writer who won the Nobel literature prize in 1976. His works changed the dominant American literature led by Hemingway and Faulkner and opened up another new era of American literature. There are many discussions among critics in the literary world, and the conclusions reached were not all the same. Some critics started with his writing techniques and believed that his novel inherits and integrates the two traditions of modernism and realism and want to classify it as a category of Western Marxism. Some apply to ethical literary criticism and make an analysis of human-nature and human-self relationship in his works. Even some critics believe that this novel distorts the image of women from the feminist point of view. This paper aims to analyze three of Saul Bellow's famous fictions, Herzog, Henderson the Rain King, More die of heartbreak from the perspectives of the spiritual evolution of the protagonists. David Galloway (1996) suggested that Bellow had only written one book from six different points of view which convey the common psychological journey of the protagonists in his works. (P138)
\end{abstract}

Index Terms—spiritual, protagonists, Saul Bellow, Search-Escape-Regeneration

\section{INTRODUCTION}

After Saul Bellow's first short novel The Hell It Can't was published on the American publication The Beacon in 1936, he never stopped his writing career. Throughout his life, he has created and published 11 novels, three novellas, four short stories, and a drama. He has won a total of 11 major awards in his entire life, among which he won the National Book Award for Fiction three times. In 1976, he reached the highest peak of the year. While receiving the Pulitzer Prize, he also won the Nobel Prize for Literature this year. Afterwards, he was also awarded O. Henry Award, National Medal of Arts, PEN/Malamud Award, Peggy V. Helmerich Distinguished Author Award and Medal for Distinguished Contribution to American Letters. Undoubtedly, he is a landmark figure in the history of American literature.

Saul Bellow's novels reflect the influence of American urban modernization process on the character and destiny of Jewish immigrants and their descendants. The city depicted not only the physical space where the story takes place, but also its particular cultural background. His novels are mostly based on the background of the chaotic urban life in form of diary bodies, homeless narratives, and stream of consciousness to reflect the perplexities of contemporary Americans in their search for self. Like Dickens, who made the great record of urban change, Bellow truly described the abundance of material wealth and the emptiness of people's spiritual life in the United States after World War II. In the late 1960s, when the United States entered the post-industrial society, individualism and money worshipism were rampant, and instrumental rationality dominated every aspect of this social life. In his works, he repeatedly compared the urban chaos and the countryside peace, showing us the strong pressure that the external world where individualism prevails to people and the threat to modern people's self-identity and moral values. Those protagonists Henderson in Henderson the Rain King, Herzog in Herzog and Professor Benn Crader in More die of heartbreak unexceptionally followed the same spiritual journey of "Search-Escape-Regeneration".

\section{SEARCH}

Bellow's works are like a new sound, searching for human dignity and value. His protagonists are usually depressed, lonely, but take the task of quest, seeking for his own destiny included in the human beings' and looking for a realization of the dignity and morality. The Elderly Eugene Henderson, twice-married and about 50-year-old millionaire, at the very beginning of the novel Henderson the Rain King, manifested the reason why he alienated from the meaningless materialism, left his family and went along to Africa. "What makes me to take this trip to Africa? There is no quick explanation. Things got worse and worse and worse and pretty soon they were too complicated."(HTRK.P1)

In Henderson's inner world he felt quite lonely and fell into a deep spiritual desperation, although Henderson was lucky to receive millions of dollars and had lived a prosperous life. After reading a lot of books he longed for searching meaningful world and got rid of the strong pressure which made him feel that life is empty and painful. Therefore, for the sake of escaping such crisis and pursuing the peace inside his mind, he chose to explore the wild world. At the same time, due to his conflict with himself, his wife, his father, his son, his sister, even his neighbors, the sound of inner voice "I want, I want" was always ringing in his ear and surrounded him continuously. Henderson tried every means to get rid 
of it, but this cry had been following him forever, and no matter how much effort he made, it lingered around him. Moreover, the chaotic mood hit him from all directions. He was overwhelmed and there was a serious crisis in his spiritual life. What was bad was that it was a condition that Henderson couldn't tell and was unclear and tortured, and he even couldn't find a reason for this. Therefore, with all these phenomena occurred, he had no choice but to escape that world and adventured to the remote tribes in Africa so as to search the real meaning of life.

The protagonist of the novel Herzog, Herzog, scholar and womanizer, is working in the rarefied atmosphere of the intellectual uplands and he is a complex person full of contradictions and self-disintegration. He is innocently romantic but also sophisticated, passionate but passive, introspective but impulsive, mentally sound but sometimes insane, emotional, and elusive. At the beginning of the novel, Herzog was on a train between Grand Central Station and Woods Hole where he is writing about 24 letters to his relatives, friends, mistresses, philosophers, historians, politicians, to the dead as well as the living, finally event to God, but never sent out. All his thoughts and preoccupations about his past, about his marriage and his other relationships, as well as his concerns about history and contemporary civilization, are exposed in these letters and in flashbacks and meditations relating to them. This approach shows that he wants to communicate freely with the outside world despite his weakness and failure in real life. Although Herzog's letter has not been published or even completed, we find that Herzog's letter is a way to search the meaning of life.

Herzog, a professor teaching in New York who specializes in the history of culture, is at his dilapidated country-house in Ludeywille, Massachusetts trying to recover from his divorce from his second wife, Madeleine, who is living in Chicago with their daughter June and Valentine Gersbach, once Herzog's best friend. Herzog considers the events of the past few days that have led him to this place. They began with his attempt to avoid the emotional pressure put on him by his mistress Ramona Donsell; he fled to the home of a friend in Vineyard Haven, but found himself too disturbed to remain there, so he return to New York and spent a night with Ramona. On the following day he visited the courthouse to meet his lawyer, Harvey Simkin. While he was there, however, he overheard a court case in which a young man and woman were being tried for the murder of the woman's child, and this generated in him a sudden fear for the safety of his own child. He flew to Chicago and, overwhelmed by an urge to kill Madeleine and Gersbach. However, his murderous urge left him when looking through a bathroom window, he saw Gersbach bathing June and suddenly realized the comic absurdity of his situation,

In More Die of Heartbreak, It superficially describes the emotional life of the narrators Kenneth and his uncle Benn suffering from setbacks and traumas, but in fact represents the spiritual dilemma faced by Western social intellectuals with advanced material civilizations. In the fiction, People have all kinds of desires: sexual desire, erotic desire, material desire, sexual desire, desire for power, greed, desire for consumption, desire to die, etc. The protagonist, Professor Benn Crader, a botanists who loves his careers and he seems to have a special relationship with plants. He not only studies their forms, understands their structure and growth cycle, but also has a special connection with them. Benn seems to be able to enter the interior of the plant and treat them as living individuals and communicate with them. It can be said that the relationship between Benn and the target plants he studied is not only the relationship between research and being researched, but also a certain kind of spiritual connection. But in addition to being in touch with plants, he also desires to communicate with people, to get love, and to establish a close relationship with people. In the fifteen years he lived alone, he found himself becoming too self-reliant, becoming needless of anyone, under the temptation of love, but also in order not to lose his lustful abilities, he began to search for a life partner.

\section{ESCAPE}

Halldorson Stephanie S.(2007) argues that literature in the 1950s continued to follow modernist antecedents in portraying the hero as a victim of the mechanizing forces of society in a spiritually exhausted world. In Saul Bellow's fiction, the protagonists of different works all suffer a journey of torture of different query of the life, they have no choice but only escape from the real world. There is an anthropological view that humans originated in Africa. Both Conrad and Hemingway saw Africa as a place where humans discovered themselves. Similarly, Bellow who obtained an anthropology degree arranged Henderson's self-exploration in Africa as the "birthplace" of mankind, allowing him to return to the origin and examine what constitutes the essence of human nature. The two tribes he went to were metaphors for different stages of human development, with different quality and value standards. Arnewi is a symbol of the matriarchal society, and the tribe of Wariri is the epitome of modern civilization. They all have important inspiration for Henderson's wisdom in searching for a true life and discovering himself.

Henderson felt the innocence, naturalness, gentleness, and primitive beauty in the Arnewi tribes, and felt harmony, identity, and peace in their Queen. As soon as Henderson entered the Arnewi tribe, he felt that he had returned to ancient times before the birth of mankind. When Henderson kissed the queen's belly in accordance with etiquette, he immediately felt a force in her body. The queen is a symbol of stability, tranquility and balance and represents harmony and unity, which Henderson lacks. Some of the truths the Queen told Henderson made Henderson more aware of himself. However, the wisdom he obtained is not sufficient to promote his complete transformation. He has no idea how to handle it effectively in the face of the frog disaster. As a result, he blew up the frogs with homemade bombs, and at the same time he destroyed the reservoirs on which the Arnewi people lived. If Arnewi is an innocent boyhood, Wariri is more like his chaotic adulthood, which is full of pain, violence, injustice and hostility. The journey in Wariri was actually a process of healing the disease of the soul. It could be divided into three major stages. The first stage was until 
Henderson became the King of Rain Sungo; The second stage was a deep conversation with the King Dahfu and imitation with the Lion Atti; The last stage was to hunt the lion who represent the dead father Gemmero. This lion-hunting activity further purified his soul and contributed to his transformation and return.

The beginning of this fiction Herzog was Herzog's escape. At the hottest time of the summer, Herzog's "stayed away from the crowd in Berkshire", and cut off all contact with the outside world, completely immersed in his own thoughts. He kept asking himself if his mind was normal. "If I'm really crazy, nothing, I don't care." he began to reflect on his own experience, but he examine his problems from his own perspective without taking into account of other people's feelings, in this case, he could not completely get out of this dilemma. He felt that everyone around him was against him: Madeleine and Valentine had affair; Madeleine's mother also opposed them; His psychiatrist and policeman did not help him. He even suspected that Ramona, the woman who deeply loved him, wanted to find someone else to marry. He felt isolated from the world and was abandoned by the entire world. Since no one can talk to, he can only write to others. These letters seem to be written to others, but actually it is the reflects on the outside world from Herzog himself and he expresses his thoughts in writing. With such a feeling, he gradually put into the embrace of nature and let everything go with. Having endured this sense of loss and disappointment in the external world, Herzog began to find a way out for himself through self-reflection and understanding of the world. In this process, he contacted the outside world as much as possible. In addition to his own pain, he also tried to think about other things, such as the meaning of human existence, death, childhood, etc. There are many philosophical, political and other aspects of thinking and monologue in the fiction. Herzog repeatedly thought about modern philosophy, thinking that modernity is a wasteland and a place where people are alienated from each other. Human beings are trapped in this dilemma, and there is no other way out than to reflect on personal knowledge. In the search for the future of mankind and the true meaning of life, he could not help but asking, "Who am I? What is the meaning of my life? Where is my future?"

The protagonist in More die of heartbreak, Benn, who is single for 15 years, is lonely and intend to seek emotional sustenance. He is known as a good candidate for many women as a lover or husband. In the search for true love, because of the lack of ability to reject women, his pure self-space was disturbed by the outside world, he had no choice but to escape. When Della Bedell, a highly constricted and obese woman, sought sex for him, he dared not refuse. After a night stand, Benn regret and tried to escape and fled to Brazil to join a plant morphology lecture, which not only caused her great pain but Della even died of cardiac arrest, and he couldn't get over it.

At the seaside luxury casino hotel in Puerto Rico, he met Caroline Bognier, who was tempting. She symbolizes beauty, sexuality, and needs and becomes another intruder in Benn's life. When asked by her proposal and when she gave him the flight number and her arrival time, Benn fled to Tokyo immediately. He insisted that marriages without true love are cages and shackles, and the naked sexual needs of women make him confused and disgusted.

After many years of "flirting, pursuing, craving, obsession, abandonment, insult, torture, sexual slavery, etc.", he decided to end all tempt with marriage. Believing that Matilda can give him true love and a peaceful marriage, he chose her. However, in the marriage life, he gradually realized that she is only really loved by money worship. Her wife's desire for money and reputation, her father's conspiracy to calculate, Benn wants to escape this cold and cruel world. In order to escape Della, who baited Benn with sex; Caroline, who took control of him by marriage, and Matilda, who forced to oppress him by money, he fled to Brazil, Japan and the Arctic respectively.

\section{REGENERATION}

Freud (1949) believed that human psychology could be divided into two parts: the conscious and the subconscious. Awareness of the subconscious can not be by me, which includes the original blind impulse and instinct. Through self-analysis, Herzog slowly understands himself and discovers his inadequacies. He is no longer obsessed with self-complaining and begins to be down-to-earth, focusing on the positive aspects of the surrounding people and real life. In this way, he began to forgive and even fall in love with his enemies - Madeline and Valentine. He gradually became aware of his own problems: the time of immersion in himself and his isolation from the outside world; Living in the life mode with his own imagines.

At the end of the novel, Herzog and his lover Ramona lived a pastoral life in the village of Rud in the countryside, eliminating the inner anxiety with the love of lovers and the beauty of nature. Bellow clearly inherited the ideas of Rousseau and other romantic writers in this respect, and he advocated that mankind should return to the nature from a modern civilized society because he believed that modern cities such as Chicago were squeezing the living space of human beings and gradually became the alienated forces of human existence. The simple nature is the home of human poetic inhabitation, and it is only in nature that people do not lose themselves. Herzog in the novel grasped the essence of life from nature and gradually got rid of the spiritual crisis caused by cultural conflicts.

In this respect, Bellow's novel Henderson Rain King seems more enlightening than Herzog. The hero Henderson's experience in the novel is exactly the opposite of Herzog's. After returning from the African wilderness to the real world, Henderson is determined to serve as a nurse to bravely assume his social responsibility and life mission.

In order to find the value of self-existence and peace, he was on the way of searching like "Pilgrim" in the same insight in a difficult journey of life. He had got an access to new power seedlings until he eventually discovered the salvation of the soul. Dahfu's attitude toward death gave Henderson a great education. Dahfu acknowledges that one must die. In the flesh, man is subject to death. However, he also believes that human soul can not die, and can be 
independent from death. Therefore, one need not fear death. The calmness and serenity of the King Dahfu before death, and his faith in the immortality of the soul, made Henderson's heart once more shocked and brought him unexpected truths. Henderson accepted it and he was no longer afraid of death. Later he risked his life to escape from the Wariri tribe and walked out of the shadow of death that had been severely imposed on him.

He decided to go back to practice the benefit of mankind. His heart's love was also revived. This can be seen as Henderson's lofty ideal of mediocrity. After all the hardships he experienced the heart came out of loneliness through recognizing the link between self and others. He made it to understand the meaning of life. And ultimately he was able to meet the spiritual over the material things cross-flow of the community. On the flight from Paris to London, Henderson was so excited to look out of the window to appreciate the scenery, while the other passengers were reading. Comparing with the former Henderson, who never cared for the things around and led a meaningless and aimless life, current Henderson had completely changed. He cared for everything. When a stewardess asked him if he can take care of a kid, instead of his former rude behavior to the little baby taken by his daughter, Henderson started to show his love to the little baby and he took good care of the baby. It obviously symbolized Henderson's rebirth. In the last chapter, Bellow demonstrated Thanksgiving Day, a lovely baby, the lion cub and so on to symbolize the renewal and mental regeneration of Henderson. We can easily feel Henderson's excitement with happiness, strength, and hope surrounding him, and he realized that only love can create the power.

Similarly, More die of heartbreak's protagonist Benn is determined to get rid of unbearable sexual devils through marriage, but he was in a moral dilemma. His second marriage was a conspiracy. Benn wanted love, while Mathilde pursued fame and fortune, and their values were completely different. In order to seek warmth, care and love, to integrate into the modern American society, Benn had to sell his personality and betray his conscience. He fought together with the Layamon and opposed his ethical will to threaten his elderly uncle Harold Vilitzer, a multi-millionaire, which is the price he paid for. In the end, Benn realized that he was just a tool that the Layamon family used to earn fame and fortune, and he was just a stepping stone, a promotion step, and an admission ticket for an ideal life for them. The novel finally wrote that Benn was ready to fly to the Arctic to study lichens in order to obtain spiritual salvation, which shows that he still has not lost his confidence in life and is still seeking the meaning of life. When he was asked about the radiation level in plants, he got the idea with the statement that offered this novel with its title: "I think more people die of heartbreak than of radiation."

\section{CONCLUSION}

It is often said that great authors write only one book. Miller (1991) draws the Bellow novel as a "peripatetic journey through events that are lost to him."(P34)The concern of human civilization and the memory of humanistic values run through almost all of Bellow's works, especially his several major works, which makes the author contemplate. In the flows of nowadays' consumer and materialistic world, people pursue money, enjoyment, success, lose their self, even lose their faith. Money worship has penetrated into every cell of society. The concern for the present reality shows the conscience and responsibility that Bellow has as a writer is also the most important and valuable system of his works. Meanwhile, his works truly reflect the spiritual emptiness of intellectuals, their pursuit of lofty rationality and exploration, and the contradictions between people and society in the era of highly developed capitalist material life. The three works Herzog, Henderson the Rain King, More die of heartbreak all demonstrated a profound reflection on intellectual crisis in this rich society, the protagonists in these works all experienced a long spiritual journey: Search-Escape-Regenaration. They all get lost and at mess at the very beginning, and in order to pursue the true meaning of life and the value of self-existence and peace, they all suffered alienation and escaped from their current surroundings to a new place to search solutions. Bellow's novels express a highly developed post-industrial society with material civilization. People enjoy the pleasure brought by luxury goods in the abundant material life, while the deep feelings of happiness are absent, and more people are not happy, satisfied, but "dead to heartbreak".

With the expansion of modernization and the natural deterioration caused by over-acquisition of natural resources, mankind has created a large amount of material wealth at the cost of nature's severe destruction. However, humanity realizes that we are only an integral part of nature and should not be self-centered. Nowadays, people began to return to nature, and humans began to rethink the relationship between man and nature and the human spiritual ecology. Henderson, Herzog and Benn, the protagonists of Bellow's works, were completely disappointed and frustrated with the entire world from the very beginning. After self-analysis and self-reflection, through the journey of "Search-Escape" they reached to Regeneration. The heroes' spirit has been sublimated, and the cornerstone of life has been re-founded after their spiritual sufferings, spiritual alienation, pathological problems and other problems emerged to the end. To soothe the wounds of people, to heal the soul, and also to provide a way out of the ecological predicament, the protagonists of Bellow's work break through the alienation and separation between humans and nature through harmonious relations, and express that humans must respect nature, return to nature so that they can reach self-regeneration eventually. 


\section{ACKNOWLEDGMENTS}

This work was supported in part by a grant from "Humanities and Social Science Project of Jiangxi Colleges and Universities, Jiangxi, China (Grant No. WGW162001)".

\section{REFERENCES}

[1] Bellow, Saul. (1996). Henderson the Rain King (HTRK). New York: Penguin Books Ltd.

[2] Bellow, Saul. (1976).Herzog. New York: Penguin Books Ltd.

[3] Bellow, Saul. (1987).More Die of Heartbreak. London: Penguin Books.

[4] David Galloway. (1996). The Absurd Hero in American Fiction (P.138)Austin: University of Texas Press.

[5] Freud, Sigmund. (1949). The Ego and the Id. London: The Hogarth Press Ltd.

[6] Halldorson, Stephanie S. (2007) The Hero in Contemporary American Fiction: The Works of Saul Bellow and Don DeLillo. NY: Continuum.

[7] Miller, R. (1991). Saul Bellow: A Biography of the Imagination. New York: St. Martin's.

Fei Luo was born in Jiangxi, China in 1981.She received her Master's degree of English and American literature from Nanchang University, China in 2012.

She is currently a lecturer in School of Foreign Language, Jiangxi Science and Technology Normal University, Jiangxi, China. Her research interests include English and American literature, English Language teaching. 